\title{
Effects of low-dose organic trace minerals on performance, mineral status, and fecal mineral excretion of sows
}

\author{
Lianxiang Ma', Junna He${ }^{1}$, Xintao Lu', Jialing Qiu', Chuanchuan Hou', Bing Liu', \\ Gang Lin', and Dongyou Yü ${ }^{1, *}$
}

\author{
* Corresponding Author: Dongyou Yu \\ Tel: +86-571-8898-2107, Fax: +86-571-8898-2107 \\ E-mail: dyyu@zju.edu.cn \\ ${ }^{1}$ College of Animal Science, Zhejiang University, Key \\ Laboratory of Animal Nutrition and Feed in East \\ China of Ministry of Agriculture, Hangzhou, Zhejiang \\ 310058, China \\ ${ }^{2}$ Institute of Quality Standards and Testing Technology \\ for Agricultural Products, Chinese Academy of \\ Agricultural Sciences, Beijing 10081, China

\section{ORCID} \\ Lianxiang $\mathrm{Ma}$ \\ https://orcid.org/0000-0001-7554-9047 \\ Junna He \\ https://orcid.org/0000-0003-1805-2434 \\ Xintao Lu \\ https://orcid.org/0000-0003-0305-3135 \\ Jialing Qiu \\ https://orcid.org/0000-0002-3440-7488 \\ Chuanchuan Hou \\ https://orcid.org/0000-0001-6731-5611 \\ Bing Liu \\ https://orcid.org/0000-0001-8641-4375 \\ Gang Lin \\ https://orcid.org/0000-0003-4106-3107 \\ Dongyou Yu \\ https://orcid.org/0000-0002-8350-3126
}

Submitted Nov 15, 2018; Revised Jan 30, 2019; Accepted Mar 24, 2019
Objective: To investigate the effects of low-dose trace mineral proteinates on reproductive performance, mineral status, milk immunoglobulin contents and fecal mineral excretion of sows.

Methods: Eighty crossbred sows (LandracexLarge White) were randomly allocated to two groups in a 135-day trail, from breeding through $21 \mathrm{~d}$ postpartum. The two treatments were inorganic trace minerals (ITM): a basal diet+inorganic iron $(\mathrm{Fe})$, copper $(\mathrm{Cu})$, manganese $(\mathrm{Mn})$, and $\operatorname{zinc}(\mathrm{Zn})$ at $90,15,25$ and $90 \mathrm{mg} / \mathrm{kg}$, respectively and organic trace minerals (OTM): a basal diet+proteinates of $\mathrm{Fe}, \mathrm{Cu}, \mathrm{Mn}$, and $\mathrm{Zn}$ at $72,12,20$, and $72 \mathrm{mg} / \mathrm{kg}$, respectively.

Results: Compared with ITM, OTM significantly increased $(p<0.05)$ the number of piglets with birthweight $>1 \mathrm{~kg}$, the litter weaning weight, and milk Fe, $\mathrm{Cu}$ contents. No significant differences $(p>0.05)$ were observed on sow hair mineral contents or immunoglobulin $M$ (IgM), IgG, and IgA contents in colostrum and milk. In comparsion to ITM, OTM decreased fecal $\mathrm{Fe}, \mathrm{Cu}, \mathrm{Mn}$, and $\mathrm{Zn}$ contents of gestating sows $(\mathrm{p}<0.01)$ and $\mathrm{Fe}, \mathrm{Mn}$, and $\mathrm{Zn}$ in lactating sows $(\mathrm{p}<0.01)$.

Conclusion: These results indicate that low-dose mineral proteinates can increase the number of piglets with birthweight $>1 \mathrm{~kg}$, the litter weaning weight and certain milk mineral concentrations while reducing fecal mineral excretion.

Keywords: Organic Trace Mineral; Reproductive Performance; Mineral Status; Fecal Mineral Excretion; Sow

\section{INTRODUCTION}

Fetal growth and development rely entirely on the maternal supply of nutrients, including trace mineral elements [1]. Mineral deficiency in the fetus induced by inadequate transfer of these minerals from the maternal system can result in poor growth and health of the conceptus with negative effects continuing well into the neonatal period [2]. Research on the nutrition of pregnant and lactating sows has been carried out to improve the quality of newborn piglets and maintain good nutritional status of sows throughout their reproductive lifespan [3]. According to Mahan et al [4], a large amount of minerals is transferred from the sow to the fetus during pregnancy, indicating the need to increase supplementation of trace minerals to recover possible depletion. Therefore, it is a common practice, under commercial conditions, to increase the dietary concentrations of supplemental minerals above National Research Council (NRC) [5] recommendations to meet the sows' needs. When conventional inorganic oxides and sulfates (e.g., $\mathrm{ZnO}, \mathrm{CuSO}_{4}$ ) in feed break down in the stomach, the released ions are free to interact with ligands, which will either allow them to remain soluble in the intestine or bind them to insoluble chelates, like phytate, and form 
low solubility salts which the animal cannot absorb. Under this condition, only a small amount of dietary iron (Fe), zinc $(\mathrm{Zn})$, copper $(\mathrm{Cu})$, and manganese $(\mathrm{Mn})$ will be utilized with $70 \%$ to $95 \%$ excreted into the environment through manure, which may lead to bioaccumulation in the soil and potentially threaten water sources due to runoff [6,7]. Organic trace minerals (mineral chelate/complex) with stable five- or six-ring structures can be protected from negative interactions with dietary antinutritional factors, remaining electrically neutral at the acidic $\mathrm{pH}$ conditions in the digestive tract, thus allowing them to be absorbed and circulated to target positions efficiently $[8,9]$.

Dietary supplementation with organic microminerals has been reported to enhance sow reproductive performance [10], improve micromineral output in mature milk of sows, increase the quantity of mineral transferred across the placenta to the fetus [11,12], and reduce fecal mineral excretion [9]. Hence, low-dose organic trace minerals may replace excess inorganic minerals, satisfying the need of sows while lowering pollution. As most research about organic trace elements in swine has focused on replacing one trace element at NRC [5] recommended levels, data on totally replacing inorganic trace minerals by the organic forms at supplemental levels recommended by commercial industrial production is limited. Therefore, the current experiment was conducted to investigate the effects of totally replacing inorganic $\mathrm{Fe}, \mathrm{Zn}, \mathrm{Cu}$, and Mn by low-dose organic proteinates on reproductive performance, mineral status, milk immunoglobulin contents and fecal mineral excretion of sows during gestation and lactation.

\section{MATERIALS AND METHODS}

\section{Animal care}

The experimental use of animals and procedures for their management and collection of tissues was performed in accordance with the Chinese Guidelines for Animal Welfare and approved by the Institutional Animal Care and Use Committee of Zhejiang University (Hangzhou, Zhejiang, China).

\section{Experimental design and treatments}

A total of 80 crossbred sows (Landrace $\times$ Large White) with similar body weight, parity and breeding date were randomly allocated to 2 treatments with 40 replicates each. Experimental diets were fed for $135 \mathrm{~d}$, from breeding through $21 \mathrm{~d}$ postpartum. The two treatments were as follows: inorganic trace minerals (ITM): a basal diet+inorganic $\mathrm{Fe}, \mathrm{Cu}, \mathrm{Mn}$, and $\mathrm{Zn}$ at levels of $90,15,25$, and $90 \mathrm{mg} / \mathrm{kg}$, respectively in gestation and lactation periods and organic trace minerals (OTM): a basal diet+organic $\mathrm{Fe}, \mathrm{Cu}, \mathrm{Mn}$, and $\mathrm{Zn}$ at levels of 72, 12, 20, and $72 \mathrm{mg} / \mathrm{kg}$ (equivalent to $80 \%$ of ITM), respectively in gestation and lactation periods. The organic $\mathrm{Fe}, \mathrm{Cu}, \mathrm{Mn}$, and $\mathrm{Zn}$ were metal proteinates, sequestered with enzymatically hydrolyzed soybean protein (Bioplex, Alltech Inc., Nicholasville, KY, USA), the analyzed values of which were $16.7 \%$, $10.2 \%, 15.8 \%$, and $16.2 \%$, respectively. The inorganic forms of these minerals were provided as $\mathrm{FeSO}_{4} \cdot 7 \mathrm{H}_{2} \mathrm{O}, \mathrm{Cu}_{2}(\mathrm{OH})_{2} \mathrm{Cl}$, $\mathrm{MnSO}_{4} \cdot \mathrm{H}_{2} \mathrm{O}, \mathrm{ZnSO}_{4} \cdot 7 \mathrm{H}_{2} \mathrm{O}$ (Weimeng feed Inc., Jiaxing, Zhejiang, China).

Diets of sows were formulated to meet or exceed NRC [5] nutrient requirements. $\mathrm{Fe}, \mathrm{Cu}$, and $\mathrm{Mn}$ exceeded the NRC [5] requirement, and $\mathrm{Zn}$ was on the limit. The ingredients and chemical composition of the basal diets are presented in Table 1 . The analyzed values of trace mineral levels in the diet are shown in Table 2.

\section{Animal housing}

During pregnancy sows were housed in individual gestation crates $\left(1.2 \mathrm{~m}^{2}\right)$ in an enclosed facility with temperatures averaging $21^{\circ} \mathrm{C} \pm 4^{\circ} \mathrm{C}$ and fed $3.0 \mathrm{~kg}$ feed daily. At approximately $107 \mathrm{~d}$ post-coitum sows were placed in individual farrowing crates $\left(1.25 \mathrm{~m}^{2}\right.$, hardened steel rod construction) and fed with the lactation treatment diet until weaning at $21 \mathrm{~d}$ postpartum. Sows were not fed on the day of farrowing, then the feed amount was raised by $1.0 \mathrm{~kg}$ daily until ad libitum feeding was reached. Piglets and sows had free access to water via a stainless-steel nipple waterer. Within $3 \mathrm{~d}$ postpartum, all piglets

Table 1. Composition and nutrient levels of basal diets (as-fed basis, \%)

\begin{tabular}{lcc}
\hline Items & Pregnancy & Lactation \\
\hline Ingredients & & \\
Corn & 59.30 & 63.00 \\
Wheat & 6.00 & - \\
Soybean meal & 19.50 & 23.50 \\
Extruded soybean & - & 3.00 \\
Fish meal & 1.00 & 2.00 \\
Wheat middling & 4.00 & 4.00 \\
Rice bran & 6.70 & - \\
soybean oil & - & 0.75 \\
Limestone & 1.35 & 1.20 \\
Dicalcium phosphate & 0.80 & 1.20 \\
Salt & 0.35 & 0.35 \\
Premix) & 1.00 & 1.00 \\
Total & 100.00 & 100.00 \\
Calculated composition & & \\
Digestible energy (MJ/kg) & 13.61 & 13.94 \\
Crude protein (\%) & 16.55 & 18.55 \\
Lysine (\%) & 0.79 & 0.95 \\
Methionine (\%) & 0.27 & 0.30 \\
Threonine (\%) & 0.61 & 0.70 \\
Calcium (\%) & 0.87 & 1.01 \\
Total phosphorus (\%) & 0.63 & 0.68 \\
Available phosphorus (\%) & 0.34 & 0.47 \\
\hline Supplemented & & $3.00010 ;$ \\
\hline
\end{tabular}

1) Supplemented per $\mathrm{kg}$ of diet: vitamin $\mathrm{A}, 10,000 \mathrm{IU}$; vitamin $\mathrm{D}_{3}, 3,000 \mathrm{IU}$; vitamin $\mathrm{E}, 50 \mathrm{lU}$; vitamin $\mathrm{K}_{3}, 2 \mathrm{mg}$; vitamin $\mathrm{B}_{1}, 2 \mathrm{mg}$; riboflavin, $4.8 \mathrm{mg}$; vitamin $\mathrm{B}_{6}, 3$ mg; vitamin $B_{12}, 20 \mu g$; niacin, 20 mg; folic acid, 3 mg; pantothenic acid, 12 mg; choline hydrochloride, $300 \mathrm{mg} ; \mathrm{Se}, 0.3 \mathrm{mg} ; \mathrm{l}, 1.5 \mathrm{mg}$. 
Table 2. Analyzed value of trace mineral levels in the diets (as-fed basis, $\mathrm{mg} / \mathrm{kg}$ )

\begin{tabular}{lcc}
\hline \multirow{2}{*}{ Trace minerals } & \multicolumn{2}{c}{ Treatments $^{1)}$} \\
\cline { 2 - 3 } Gestating feed & ITM \\
Fe & $304.2(90)$ & $283.1(72)$ \\
Cu & $29.5(15)$ & $25.6(12)$ \\
Mn & $67.4(25)$ & $61.7(20)$ \\
Zn & $129.4(90)$ & $116.5(72)$ \\
Lactating feed & & \\
Fe & $321.5(90)$ & $302.1(72)$ \\
Cu & $34.7(15)$ & $29.9(12)$ \\
Mn & $64.4(25)$ & $60.9(20)$ \\
Zn & $118.5(90)$ & $103.8(72)$ \\
\hline
\end{tabular}

Values in parenthesis are the amounts of added minerals.

1) ITM, inorganic trace minerals; OTM, organic trace minerals.

were processed (i.e., ear notched and teeth clipped), injected with $200 \mathrm{mg}$ of Fe (iron dextran), and the litter size was equalized between sows within treatments.

\section{Sampling and processing}

Fecal samples from 6 sows per treatment were collected three times daily on $\mathrm{d} 60$ of gestation and day of parturition, then mixed, homogenized and pooled per sow. Each sample was dried in an oven at $65^{\circ} \mathrm{C}$ for $48 \mathrm{~h}$, then finely ground in a stainless blade grinder to pass a $1 \mathrm{~mm}$ screen. Meanwhile, the same sows were selected at the same day to collect approximately 2 to $4 \mathrm{~g}$ hair along the topline of the shoulder. The hair was washed with neutral detergent, soaked in acetone for $5 \mathrm{~min}$ and rinsed in double distilled water 3 times, then dried for $24 \mathrm{~h}$ at $95^{\circ} \mathrm{C}$ and cut into $0.5 \mathrm{~cm}$ lengths to obtain a homogeneous sample [13]. Colostrum and milk were collected (n $=6$ per treatment) by hand expression from all functional mammary glands on $\mathrm{d} 0$ and 10 postpartum. The selected sows were each injected with $1 \mathrm{~mL}$ oxytocin $10 \mathrm{~min}$ prior to milking, and followed by a warm water wash of the udder. Great care was taken to completely milk all the mammary glands to get milk samples of approximately $20 \mathrm{~mL}$. About $10 \mathrm{~mL}$ of each sample was centrifuged to collect the whey with an ultracentrifuge at $3,000 \times \mathrm{g}$ at $4^{\circ} \mathrm{C}$ for $30 \mathrm{~min}$ to remove free fat [14]. All whey, colostrum and milk samples were frozen at $-20^{\circ} \mathrm{C}$ for later analysis.

Piglets were weighed within $2 \mathrm{~h}$ of birth, the litter size of total born, born alive, the stillborn and mummies were recorded. On weaning at $\mathrm{d} 21$, the litter size and litter weight were recorded likewise. The weights of dead piglets were documented throughout the entire lactation to calculate average daily gain (ADG) and pre-weaning livability of piglets. On farrowing and weaning day, the backfat thickness of sows at $6 \mathrm{~cm}$ perpendicular to the dorsal midline of the last rib was measured using Lean meter (Renco, NY, New York, USA). Feed intake of sows during lactation was recorded daily.

\section{Analytical methods}

Diets, feces and hair were analyzed for $\mathrm{Fe}, \mathrm{Cu}, \mathrm{Mn}$, and $\mathrm{Zn}$ concentrations via an inductively coupled plasma optical emission spectrometer (ICP-OES) (Perkin Elmer Scientific Inc., Billerica, MA, USA) after wet ashing with $3 \mathrm{~mL}$ nitric acid and $1 \mathrm{~mL}$ hydrogen peroxide in a microwave digester (CEM Corp., Matthews, NC, USA; method 999.10; AOAC [15]). A special alkaline solution was used to process milk samples: 1 g ethylene diamine tetraacetic acid and $10 \mathrm{~mL}$ ammonia solution were added to $50 \mathrm{~mL}$ double distilled water, agitated, and followed by $10 \mathrm{~mL}$ isopropanol and $1 \mathrm{~mL} 1 \%$ Triton X-100 aqueous solution and double distilled water was used to made up to $100 \mathrm{~mL}$. Colostrum and milk samples were thawed at room temperature. Then $0.2 \mathrm{~mL}$ of each milk sample was mixed with $0.5 \mathrm{~mL}$ of the strong alkaline solution, then vortex mixed for $5 \mathrm{~s}$ and made up to a volume of $5 \mathrm{~mL}$ with double distilled water [16]. All samples were introduced into the inductively coupled plasma mass spectrometry (ICP-MS) (Perkin Elmer Scientific Inc., USA).

The concentrations of immunoglobulin G (IgG), IgA, and IgM were determined using enzyme-linked immunosorbent assay kits (Jiangsu Mei Biao in Technology Co., Ltd. Yancheng, Jiangsu, China).

\section{Statistical analysis}

Statistics analysis was performed with SPSS 22.0 Software (SPSS, Inc., Chicago, IL, USA). The data were analyzed by Ttest and the results are presented as mean and standard error of mean. Significance was declared at $p<0.05$, and $p<0.10$ was considered to represent tendencies between treatments.

\section{RESULTS}

\section{Reproductive performance}

Table 3 shows the reproductive performance of sows fed different sources of trace minerals. Compared with ITM, OTM increased $(p<0.05)$ the number of piglets with birth weight $>1 \mathrm{~kg}$ by $6.5 \%$. Litter weaning weight was increased $15.8 \%$ $(\mathrm{p}<0.05)$ with OTM. However, there were no significant differences for litter size of total born, born alive, litter birth weight, weaning survival rate or ADG of piglets between the two treatments.

\section{Milk trace minerals contents}

OTM increaed milk Fe and $\mathrm{Cu}$ contents $(\mathrm{p}<0.01)$ and tended to increase colostrum $\mathrm{Zn}$ content $(\mathrm{p}=0.09)$ compared with ITM (Table 4).

\section{Immunoglobulin contents}

Table 5 shows that there were no significant differences in colostrum and milk IgA, IgG, and IgM contents from sows fed diets supplemented with ITM or OTM. 
Table 3. Effect of organic trace minerals on reproductive performance of sows

\begin{tabular}{lcccc}
\hline Parameters & ITM $^{1)}$ & OTM $^{1)}$ & SEM & p-value \\
\hline Parity $(\mathrm{n})$ & 2.58 & 2.65 & 0.18 & 0.77 \\
Back fat thickness at farrowing $(\mathrm{mm})$ & 16.39 & 16.56 & 0.60 & 0.85 \\
Back fat thickness at weaning (mm) & 14.97 & 15.19 & 0.48 & 0.76 \\
Lactation feed intake $(\mathrm{kg} / \mathrm{d})$ & 5.63 & 5.65 & 0.04 & 0.73 \\
Total born (n) & 11.75 & 11.81 & 0.22 & 0.90 \\
Born alive (n) & 11.05 & 11.28 & 0.19 & 0.55 \\
Piglets with birth weight $>1 \mathrm{~kg}(\mathrm{n})$ & 9.83 & 10.47 & 0.15 & 0.03 \\
Stillborn and mummies $(\mathrm{n})$ & 0.75 & 0.56 & 0.11 & 0.38 \\
Litter birth weight $(\mathrm{kg})$ & 15.72 & 16.69 & 0.31 & 0.12 \\
Piglet birth weight $(\mathrm{kg})$ & 1.43 & 1.49 & 0.02 & 0.18 \\
Pigs at weaning $(\mathrm{n})$ & 9.52 & 10.45 & 0.47 & 0.17 \\
Litter weaning weight $(\mathrm{kg})$ & 59.41 & 68.77 & 2.82 & 0.02 \\
Piglet weaning weight $(\mathrm{kg})$ & 6.48 & 6.72 & 0.23 & 0.48 \\
Weaning survival rate $(\%)$ & 86.34 & 91.33 & 2.46 & 0.15 \\
1 to 21 d ADG $(\mathrm{g} / \mathrm{d})$ & 214.57 & 229.23 & 9.92 & 0.25 \\
\hline
\end{tabular}

Values are presented as mean and SEM; $n=40$.

SEM, standard error of the mean; $A D G$, average daily gain.

1) ITM, inorganic trace minerals; OTM, organic trace minerals at $80 \%$ of ITM.

\section{Hair and fecal trace minerals concentrations}

As shown in Table 6, compared with ITM, OTM significantly decreased $(\mathrm{p}<0.01) \mathrm{Fe}, \mathrm{Mn}, \mathrm{Cu}$, and $\mathrm{Zn}$ contents in the manure of gestating sows by $33.5 \%, 15.6 \%, 77.3 \%$, and $37.8 \%$, respectively. Fecal Fe, Mn, and $\mathrm{Zn}$ contents were reduced during lactation by $47.7 \%, 28.8 \%$, and $56.1 \%$, respectively ( $\mathrm{p}<0.01$ ). However, the contents of $\mathrm{Fe}, \mathrm{Cu}, \mathrm{Mn}$, and $\mathrm{Zn}$ in sows' hair throughout gestation and lactation had no distinct differences between the treatments.

\section{DISCUSSION}

During the gestation and lactation periods, sows have an

Table 4. Effect of organic trace minerals trace minerals contents in sows' milk $(\mu \mathrm{g} / \mathrm{mL})$

\begin{tabular}{lcccc}
\hline Items & ITM $^{\mathbf{1}}$ & OTM $^{\mathbf{1}}$ & SEM & p-value \\
\hline Parity (n) & 2.67 & 2.50 & 0.21 & 0.60 \\
Backfat thickness (mm) & 16.23 & 16.33 & 0.50 & 0.90 \\
Lactation feed intake (kg/d) & 5.64 & 5.65 & 0.03 & 0.75 \\
Colostrum & & & & \\
Fe & 13.69 & 13.57 & 1.37 & 0.96 \\
Mn & 0.06 & 0.05 & 0.01 & 0.29 \\
Cu & 4.32 & 3.44 & 0.68 & 0.42 \\
Zn & 15.95 & 23.41 & 3.16 & 0.09 \\
Milk & & & & \\
Fe & 12.39 & 18.06 & 2.11 & 0.03 \\
Mn & 0.09 & 0.14 & 0.03 & 0.22 \\
Cu & 0.86 & 1.53 & 0.23 & 0.01 \\
Zn & 8.79 & 8.20 & 0.76 & 0.64 \\
\hline
\end{tabular}

Values are presented as mean and SEM; $n=6$.

SEM, standard error of the mean.

1) ITM, inorganic trace minerals; OTM, organic trace minerals at $80 \%$ of ITM.
Table 5. Effect of organic trace minerals on immunoglobulin contents in sows' milk $(\mu \mathrm{g} / \mathrm{mL})$

\begin{tabular}{lcccc}
\hline Items & ITM $^{1)}$ & OTM $^{\text {1) }}$ & SEM & p-value \\
\hline Colostrum & & & & \\
IgM & 113.26 & 123.13 & 5.48 & 0.46 \\
$\operatorname{lgG}$ & 426.15 & 447.87 & 17.62 & 0.58 \\
$\operatorname{lgA}$ & 118.51 & 121.41 & 6.24 & 0.74 \\
Milk & & & & \\
$\operatorname{lgM}$ & 101.67 & 107.33 & 4.88 & 0.58 \\
$\lg G$ & 366.12 & 321.29 & 11.76 & 0.10 \\
$\lg A$ & 134.40 & 129.08 & 5.20 & 0.70 \\
\hline
\end{tabular}

Values are presented as mean and SEM; $n=6$.

SEM, standard error of the mean; Ig, immunoglobulin.

1) ITM, inorganic trace minerals; OTM, organic trace minerals at $80 \%$ of ITM.

increased demand for trace elements such as $\mathrm{Fe}, \mathrm{Cu}, \mathrm{Mn}$, and $\mathrm{Zn}$ to support their growth and production needs. Fetal growth and development rely entirely on the maternal nutrient supply, including trace minerals, deficiency of which will result in poor growth and health of the conceptus [1,2]. It has been reported that iron amino acid chelates could increase the proportion of iron transferred to fetus through the placenta and obtain higher piglet growth rate $[12,17]$, and that $\mathrm{Cu}$ proteinate could reduce the weight loss of lactating sows while improving the litter weaning weight [18]. In addition, organic trace minerals complexes $(\mathrm{Cu}, \mathrm{Fe}, \mathrm{Mn}, \mathrm{Zn}$, and $\mathrm{Se}$ ) increased the number of pigs born (total and live),

Table 6. Effect of organic trace minerals on trace minerals contents in hair and feces of sows (mg/kg, as air-dry basis)

\begin{tabular}{lccccc}
\hline Items & & ITM $^{1)}$ & OTM $^{\text {1) }}$ & SEM & p-value \\
\hline Hair & Gestation & & & & \\
& Fe & 19.00 & 20.64 & 2.96 & 0.74 \\
& Mn & 3.84 & 3.21 & 0.69 & 0.56 \\
Cu & 15.26 & 14.03 & 0.55 & 0.12 \\
& Zn & 358.98 & 342.30 & 29.92 & 0.73 \\
& Lactation & & & & \\
Fe & 28.47 & 31.06 & 1.76 & 0.35 \\
& Mn & 5.99 & 4.88 & 0.85 & 0.39 \\
Cu & 15.68 & 15.08 & 0.69 & 0.57 \\
Feces & Zn & 433.52 & 468.47 & 30.63 & 0.45 \\
& Gestation & & & \\
Fe & $2,350.04$ & $1,760.90$ & 152.81 & $<0.01$ \\
Mn & $1,051.57$ & 910.06 & 39.55 & $<0.01$ \\
& Cu & 404.64 & 228.24 & 42.44 & $<0.01$ \\
Zn & $1,783.92$ & $1,294.82$ & 119.90 & $<0.01$ \\
& Lactation & & & & \\
Fe & $3,411.54$ & $2,310.22$ & 303.59 & $<0.01$ \\
Mn & $1,199.74$ & 931.76 & 69.19 & $<0.01$ \\
Cu & 319.78 & 341.45 & 11.14 & 0.19 \\
Zn & $2,330.00$ & $1,492.99$ & 221.31 & $<0.01$ \\
\hline
\end{tabular}

Values are presented as mean and SEM; $n=6$.

SEM, standard error of the mean.

1) ITM, inorganic trace minerals; OTM, organic trace minerals at $80 \%$ of ITM. 
litter birth weight [10] and individual piglet weight at birth and at weaning [3]. In contrast, Acda and Chae [19] demonstrated that organic trace elements produced no effect on the number of piglets total born, born alive and weaned, which was in accordance with the results of our study, this could result from the complexity of the female reproductive process. However, it was observed in the present study that compared with ITM, sows fed the OTM diet had more piglets with birthweight $>1 \mathrm{~kg}$, which is a crucial indicator in commercial pig production.

Serum and tissues are commonly used to reflect body mineral status $[11,20]$. However, in the current study, hair of sows was collected to determine $\mathrm{Fe}, \mathrm{Cu}, \mathrm{Mn}$, and $\mathrm{Zn}$ concentrations instead of serum in consideration of the negative effect on the conceptus induced by blood sampling stress. Moreover, hair had been reported as an appropriate alternative for analysis of minerals in humans [21] and swine [22], as it could be readily obtained, stored and reflect the average load of minerals in the body at a particular time. In the present study, no differences were observed in hair mineral contents of sows during gestation and lactation when fed ITM or OTM, indicating that organic trace minerals at $80 \%$ of ITM levels may be sufficient for internal absorption and utilization by commercial sows. Colostrum and milk are known to provide nutritional support to neonates to aid their development, and the trace minerals in them may be influenced by diet composition and bioavailability due to transfer from plasma to the mammary gland [8]. Some studies have shown that $\mathrm{Fe}$ and $\mathrm{Cu}$ contents in milk are generally resistant to dietary levels, whereas $\mathrm{Zn}$ and $\mathrm{Mn}$ concentrations in milk increased with increasing dietary levels in the dam [23]. Interestingly, Peters and Mahan [11] observed a linear relationship between milk $\mathrm{Zn}$ and $\mathrm{Cu}$ contents and dietary supplementation levels. In the current study, milk $\mathrm{Fe}$ and $\mathrm{Cu}$ increased and colostrum $\mathrm{Zn}$ content tended to increase with dietary supplementation of organic trace minerals complexes, which was consistent with the results of Acda and Chae [19] and Bertechini et al [3]. This implies that organic $\mathrm{Fe}$ and $\mathrm{Cu}$ can be more efficiently utilized and transferred to mammary glands, possibly resulting in heavier litter weight. One possible interpretation is that organic $\mathrm{Fe}$ can be transferred more effectively from placenta to the fetus [12]. The above results indicate that organic trace minerals have higher bioavailability and can exert the same or better growth-promoting effect than higher levels of inorganic forms.

Newborn piglets with immature immune systems rely entirely on colostrum immunoglobulins, mainly IgG to provide passive immunity. As reported by Kielland et al [24], increasing IgG level in colostrum would improve the level in piglets and potentially enhance preweaning survival. Furthermore, the sensitivity of neonatal piglets to pathogen infection can be reduced by immunoglobulins in colostrum and milk [14,
25]. Ig A is a major immunoglobulin in milk that helps protect piglets against pathogenic bacteria, commensal bacteria and food antigens in the local digestive tract [14]. Trace minerals $(\mathrm{Fe}, \mathrm{Zn}$, and $\mathrm{Mn}$ ) are vital for the formation and stabilization of immune system as enzyme co-factors and are involved in the regulation of immune cell repair, proliferation, and gene transcription, deficiency of which may affect normal immune function and reduce serum immunoglobulin contents [26]. Wu et al [27] reported that zinc amino acid chelates increased the contents of IgG, IgA, and IgM in serum of weaned pigs and lymphocyte transformation rate. Iron amino acid chelate was also observed to elevate IgG level in suckling pigs' serum [28]. Moreover, pregnant sows fed with organic trace minerals complexes (Fe, $\mathrm{Zn}, \mathrm{Mn}, \mathrm{Se}$, and $\mathrm{Cr}$ ) considerably improved serum IgG levels [26]. In this study, no differences were observed on the contents of IgG, IgM, or IgA in the colostrum and milk of sows, implying that OTM at $80 \%$ of ITM levels was sufficient, having the same effect as $100 \%$ ITM in allowing lactating sows to secrete immunoglobulins.

Minerals in excrement are mainly derived from unabsorbed trace minerals in the diet and those excessively absorbed and excreted by the bile under the action of homeostatic balance regulation [20]. Thus, the supplemental levels and sources of trace minerals in the diet are the main factors affecting micromineral emissions in excrement [29,30]. Dietary supplementation with low levels of trace minerals has been reported to reduce micromineral concentrations in the manure of nursery pigs [30] and grower-finisher pigs [20]. Moreover, using organic trace elements totally or individually to replace the inorganic trace minerals also decreased fecal trace elements excretion [30,31]. However, there are few reports of the fecal micromineral excretion of gestating and lactating sows when inorganic $\mathrm{Fe}, \mathrm{Cu}, \mathrm{Mn}$, and $\mathrm{Zn}$ was totally replaced by organic trace elements at low levels. Results from the present study showed that reducing organic trace minerals $(\mathrm{Fe}, \mathrm{Cu}$, $\mathrm{Mn}$, and $\mathrm{Zn}$ ) supplementation to $80 \%$ of the commercially recommended levels reduced fecal $\mathrm{Fe}, \mathrm{Cu}, \mathrm{Mn}$, and $\mathrm{Zn}$ excretion by $25.1 \%, 13.5 \%, 43.7 \%$, and $27.4 \%$, respectively in gestating sows. While fecal $\mathrm{Fe}, \mathrm{Mn}$, and $\mathrm{Zn}$ concentrations were reduced by $32.3 \%, 22.3 \%$, and $35.9 \%$, respectively in lactating sows. These reductions occurred without adverse effects on performance. Similarly, our team also found, in previous work, that fecal contents of Fe, $\mathrm{Cn}, \mathrm{Zn}$, and Se were significantly decreased when growing-fattening pigs consumed organic trace mineral compounds ( $\mathrm{Fe}, \mathrm{Cn}, \mathrm{Mn}, \mathrm{Zn}$, and $\mathrm{Se}$ ) or were fed diets without trace elements inclusion in comparison to those receiving equivalent inorganic trace minerals at commercially recommended levels without compromising growth performance [20]. The possible interpretation could be that organic trace minerals with stable five- or six-membered ring structures can be more completely 
absorbed by the intestinal brush border through amino acid or peptide absorption routes and protected from interference in digestive tract from compounds such as phytate and calcium, resulting in higher bioavailability and lower fecal mineral excretion [18]. These routes of absorption need further exploration to fully explain the ability to feed organic trace minerals at low levels without compromising performance.

In summary, total replacement of inorganic trace element compounds ( $\mathrm{Fe}, \mathrm{Cu}, \mathrm{Mn}$, and $\mathrm{Zn}$ ) by mineral proteinates at approximately $80 \%$ increased the number of piglets with birthweight $>1 \mathrm{~kg}$, litter weaning weight, and milk mineral levels and reduced trace mineral excretion of commercial gestating and lactating sows, while having no significant influences on immunoglobulins IgG, IgA, and IgM levels in colostrum and milk of the sows.

\section{CONFLICT OF INTEREST}

We certify that there is no conflict of interest with any financial organization regarding the material discussed in the manuscript.

\section{ACKNOWLEDGMENTS}

This study was funded by the Zhejiang Science and Technology Department (grant numbers 2015C02022). The procedures and the animals used in this experiment were approved by Dunhao Agriculture \& Stockbreeding Co., Ltd, Jiaxing, Zhejiang. The authors would like to acknowledge Dr. Dongyou YU, Dr. Gang LIN for their elaborate guidance; Mr. Chuanchuan HOU, Mr. Tianlong ZHU for animal husbandry work; and Mr. Hongjun WANG for experimental feed processing.

\section{REFERENCES}

1. Van Saun RJ. Effect of nutrition on reproduction in llamas and alpacas. Theriogenology 2008;70:508-14. https:/doi.org/ 10.1016/j.theriogenology.2008.04.025

2. Hostetler CE, Kincaid RL, Mirando MA. The role of essential trace elements in embryonic and fetal development in livestock. Vet J 2003;166:125-39. https://doi.org/10.1016/S1090-0233 (02)00310-6

3. Bertechini AG, Fassani EJ, de Brito JÁG, Barrios PR. Effects of dietary mineral bioplex in pregnant and lactating sow diets on piglet performance and physiological characteristics. Rev Bras Zootec 2012;41:624-9. https://doi.org/10.1590/S151635982012000300022

4. Mahan DC, Watts MR, St-pierre N. Macro- and micromineral composition of fetal pigs and their accretion rates during fetal development. J Anim Sci 2009;87:2823-32. https://doi. org/10.2527/jas.2008-1266

5. NRC. Nutrient requirements of swine. 11th rev. ed. Washing- ton, DC, USA: National Academy Press; 2012.

6. Mcdowell RW, Sharpley AN. Phosphorus solubility and release kinetics as a function of soil test $\mathrm{P}$ concentration. Geoderma 2003;112:143-54. https://doi.org/10.1016/S0016-7061(02) 00301-4

7. Besser JM, Dwyer FJ, Ingersoll CG, Wang N. Early Life-stage toxicity of copper to endangered and surrogate fish species. Washington, DC, USA: US Environmental Protection Agency. EPA/600/R-01/051, 2001.

8. Acda SP, Chae BJ. A review on the applications of organic trace minerals in pig nutrition. Pakistan J Nutr 2002;1:2530. https://doi.org/10.3923/pjn.2002.25.30

9. Burkett JL, Stalder KJ, Powers WJ, et al. Effect of inorganic and organic trace mineral supplementation on the performance, carcass characteristics, and fecal mineral excretion of phase-fed, grow-finish swine. Asian-Australas J Anim Sci 2009;22:1279-87. https://doi.org/10.5713/ajas.2009.70091

10. Peters JC, Mahan DC. Effects of dietary organic and inorganic trace mineral levels on sow reproductive performances and daily mineral intakes over six parities. J Anim Sci 2008;86: 2247-60. https://doi.org/10.2527/jas.2007-0431

11. Peters JC, Mahan DC, Wiseman TG, Fastinger ND. Effect of dietary organic and inorganic micromineral source and level on sow body, liver, colostrum, mature milk, and progeny mineral compositions over six parities. J Anim Sci 2010;88: 626-37. https://doi.org/10.2527/jas.2009-1782

12. Ashmead HD, Graff DJ. Placental transfer of chelated iron. Proceedings of the International Pig Veterinary Society Congress; Mexico; 1982. p. 207.

13. Roug A, Swift PK, Gerstenberg G, et al. Comparison of trace mineral concentrations in tail hair, body hair, blood, and liver of mule deer (Odocoileus hemionus) in california. J Vet Diagn Invest 2015;27:295-305. https://doi.org/10.1177/10406387155 77826

14. Liu ST, Hou WX, Cheng SY, Shi BM, Shan AS. Effects of dietary citric acid on performance, digestibility of calcium and phosphorus, milk composition and immunoglobulin in sows during late gestation and lactation. Anim Feed Sci Technol 2014;191:67-75. https://doi.org/10.1016/j.anifeedsci.2014.01.017

15. AOAC. Official methods of analysis of AOAC International, 18th edn. Association of Official Analytical Chemists Int, Arlington, VA, USA: AOAC International; 2000.

16. Mohd-Taufek N, Cartwright D, Davies M, et al. The simultaneous analysis of eight essential trace elements in human milk by ICP-MS. Food Anal Methods 2016;9:2068-75. https:// doi.org/10.1007/s12161-015-0396-Z

17. Tummaruk P, Tantilertcharoen R, Pondeenana S, Buabucha $\mathrm{P}$, Virakul P. The effect of an iron glycine chelate supplement on the haemoglobin and the haematocrit values and reproductive traits of sows. Thai J Vet Med 2003;33:45-53.

18. Xu W, Dong QG, Wang GQ, Luo L, Wang T. Effects of Bioplex Copper on sow productivity, piglet growth performance and 
serum mineral contents. Acta Agriculturae Zhejiangensis 2010;22:469-73.

19. Acda SP, Chae BJ. Effects of organic trace mineral supplementation on sows' reproductive and neonates' growth performance through 2 wk postweaning. Asian-Australas J Anim Sci 2002; 15:1312-8. https://doi.org/10.5713/ajas.2002.1312

20. Liu B, Xiong PW, Chen NN, et al. Effects of replacing of inorganic trace minerals by organically bound trace minerals on growth performance, tissue mineral status, and fecal mineral excretion in commercial grower-finisher pigs. Biol Trace Elem Res 2016;173:316-24. https://doi.org/10.1007/s12011-0160658-7

21. Zhang W, Ren A, Yang Z. Correlation studies of trace elements in mother's hair, venous blood and cord blood. Chinese J Reprod Health 2005;4:209-12.

22. Zhan K, Zhan JS, Zhao GQ, Huo YJ. Effects of iron and zinc complex amino acid chelate on absorption metabolism of iron and zinc of finishing pigs. Chinese J Anim Nutr 2014;8:2320-6.

23. Hill GM, Miller ER, Ku PK. Effect of dietary zinc levels on mineral concentration in milk. J Anim Sci 1983;57:123-9. https://doi.org/10.2527/jas1983.571123x

24. Kielland C, Rootwelt V, Reksen O, Framstad T. The association between immunoglobulin $\mathrm{g}$ in sow colostrum and piglet plasma. J Anim Sci 2015;93:4453-62. https://doi.org/10.2527/jas.20148713

25. Hurley WL, Theil PK. Perspectives on immunoglobulins in colostrum and milk. Nutrients 2011;3:442-74. https://doi. org/10.3390/nu3040442

26. Han W. Effects of Allples on reproducibility and blood biochemical indices of pregnancy sows [master's thesis]. Changsha, China: Hunan Agriculture University; 2010.

27. Wu YC, Guo S, Yin ZX, Tang GW, Su LJ. Effect of zinc amino acid chelate on immunity of weaned pigs. Anim Husb Vet Med 2008;40:58-9.

28. Liu HF, Zhou AG, Wang SZ, Cui Q. Effect of amino acid chelate iron on performance of lactating piglet. China Feed 2003;23: 16-20. https://doi.org/10.3969/j.issn.1004-3314.2003.23.009

29. He WL, Zheng WG, Ren HT, Zhang JH, Zhang ZQ. Effect of level of copper, iron and zinc in diet on the growth performance and elements in feeds of piglets. Heilongjiang Anim Sci Vet Med 2005; 2:23-5.

30. Creech BL, Spears JW, Flowers WL, et al. Effect of dietary trace mineral concentration and source (inorganic vs. chelated) on performance, mineral status, and fecal mineral excretion in pigs from weaning through finishing. J Anim Sci 2004;82:21407. https://doi.org/10.2527/2004.8272140x

31. Veum TL, Carlson MS, Wu CW, Bollinger DW, Ellersieck MR. Copper proteinate in weanling pig diets for enhancing growth performance and reducing fecal copper excretion compared with copper sulfate. J Anim Sci 2004;82:1062-70. https://doi. org/10.2527/2004.8241062x 